\begin{tabular}{|c|c|c|}
\hline KULTURA & $\begin{array}{l}\text { POLSKA AKADEMIA NAUK } \\
\text { KOMITET SOCJOLOGII } \\
\text { INSTYTUT STUDIÓW POLITYCZNYCH }\end{array}$ & ISSN 0023-5172 \\
\hline ULECLE & NOWE MECHANIZMY WYTWAF & NIA KULTUR \\
\hline
\end{tabular}

FILIP SCHMIDT

Uniwersytet im. Adama Mickiewicza w Poznaniu

\title{
NIECZYSTE RELACJE \\ AMBIWALENCJE I NAPIĘCIA W DZISIEJSZYCH ZWIĄZKACH INTYMNYCH — KRYTYCZNA ANALIZA KONCEPCJI ANTHONY'EGO GIDDENSA
}

Teksty z zakresu socjologii rodziny rzadko pojawiają się w Polsce w ogólnotematycznych czasopismach naukowych (Przybył, Żurek 2007, s. 508), brakuje też nowszych podręczników tej subdyscypliny (Przybył, Żurek 2007, s. 505) ${ }^{1}$, nieco częściej zaś podejmowana jest problematyka przemian rodziny, intymności i związków intymnych, być może dlatego, że wypowiadały się na ten temat największe socjologiczne autorytety (np. Bauman 1998; Luhmann 2003; Beck, Beck-Gernsheim 2005). Dobrze wpisuje się on bowiem $\mathrm{w}$ popularną $\mathrm{w}$ socjologii dyskusję na temat tego, czym współczesność różni się od przeszłości, a zwłaszcza zmian, jakie zaszły w obszarze życia codziennego po rewolucji kulturowej lat sześćdziesiątych i siedemdziesiątych $\mathrm{XX}$ wieku.

Jedną z takich analiz jest koncepcja przemian intymności Anthony'ego Giddensa, w Polsce w ostatnich latach częściej omawiana (np. Sekuła 2006; Lew-Starowicz 2007; Ronek 2008) z uwagi na ukazanie się tłumaczenia Przemian intymności (Giddens 2006) ${ }^{2}$, a w zachodnich artykułach poświęconych związkom intymnym, miłości i seksualności wielokrotnie komentowana już wcześniej (zob. np. Schmidt G. i in. 2003; Bawin-Legros 2004; Starke 2005), nieraz też krytykowana (zob. Jamieson 1999; Meuser 1998b; Holmes 2004). Praca Giddensa prowokuje bowiem do dyskusji nad kilkoma wciąż powracającymi problemami.

Adres do korespondencji: fschmidt@amu.edu.pl

${ }^{1}$ Artykuł powstał zanim w październiku 2010 r. ukazała się Socjologia rodziny Tomasza Szlendaka, która często jest traktowana jako nowy polski podręcznik z zakresu tej subdyscypliny.

2 Dalej w tekście przy powołaniach na to wydanie i cytatach $z$ niego podaję jedynie numer strony w nawiasie. 
Po pierwsze, dyskusja dotyczy kwestii zmiany i ciągłości kulturowej, a dokładniej - tempa tej zmiany i form, jakie ona przybiera. Po drugie, tego, jak przemiany kulturowe wplecione są w przemiany więzi społecznych i jak można trafnie opisywać mechanizmy i przebieg zmian - a więc uwzględniając pojawiające się napięcia i dylematy, które aktorzy społeczni muszą rozstrzygać na co dzień.

Przyglądając się tym kwestiom w kontekście przemian związków intymnych, można dostrzec kolejne bardziej szczegółowe problemy. Po pierwsze, $\mathrm{w}$ jakim stopniu pewne tendencje $\mathrm{w}$ przemianach intymności dają się uogólnić na różne środowiska społeczne, a w jakim dotyczą tylko tych bardziej awangardowych, a także w jakim stopniu różne modele związków intymnych współistnieją ze sobą. Kolejne pytanie dotyczy tego, jakie formy przyjmuje nakierowana na związek refleksyjność dwojga ludzi oraz jaka jest jej relacja z innymi regulatorami zachowań ludzkich, takimi jak przyzwyczajenia czy słabo uświadamiane i werbalizowane przekonania i oczekiwania co do kształtu związku i codzienności.

Słabości pracy Giddensa można upatrywać w tym, że trudno udzielić pełnej odpowiedzi na te pytania, opierając się głównie na analizie dyskursów poradników i literatury terapeutycznej ${ }^{3}$. Dość ryzykowne wydaje się zarówno utożsamianie treści tego typu literatury $z$ treścią przemian kulturowych, jak i utożsamianie przedstawionych $\mathrm{w}$ niej założeń dotyczących funkcjonowania wiedzy ludzkiej i działania z założeniami analizy socjologicznej. W rezultacie model analizy stosowany przez Giddensa niesie ze sobą wiele daleko idących uproszczeń. Widoczne staje się to zwłaszcza wtedy, gdy przyjrzymy się popularnym odczytaniom i zastosowaniom pracy Giddensa. Dyskusja nad praca Giddensa jest istotna także dlatego, że wiele $z$ jej argumentów i słabości uwidacznia się w innych, nie tylko socjologicznych, ale i potocznych dyskursach na temat dzisiejszych związków intymnych.

W tych rozważaniach na początku zrekonstruuję najważniejsze elementy Przemian intymności. Potem wskazane wyżej kwestie podejmę na przykładzie prac domowych, stanowiących bardzo ważny element codzienności związków oraz wskaźnik ewentualnych przemian intymności, aby na koniec powrócić do ogólniejszych pytań dotyczących kwestii zmiany i ciągłości kulturowej oraz tego, jak przemiany kulturowe wplecione są $\mathrm{w}$ przemiany więzi społecznej. Zamierzam zatem nie tyle dyskutować nad modelem przemian intymności Giddensa, ile podjąć ogólniejszy problem — jak adekwatnie opisywać $\mathrm{w}$ socjologii związki intymne i życie codzienne oraz przemiany w tych obszarach.

3 I to w dodatku - na jednym tylko ich rodzaju, jednym dyskursie, podczas gdy także pole tego typu literatury jest bardzo zróżnicowane i odzwierciedla zróżnicowanie konkurujących dziś ze sobą wizji związku i intymności; zob. Gdula 2009. Kwestię tę jedynie tu sygnalizuję. 


\section{GIDDENS O ZWIAZZKACH I INTYMNOŚCI}

\section{OD AMOUR PASSION PRZEZ MIŁOŚĆ ROMANTYCZNĄ AŻ DO CZYSTEJ RELACJI}

Punktem wyjścia rozważań Giddensa jest założenie o czasowym następowaniu po sobie $\mathrm{w}$ historii europejskich społeczeństw trzech rodzajów więzi między kobietą i mężczyzną. Pierwsza to amour passion - miłość namiętna, „wyraz integralnej więzi między miłością a seksem” (s. 52), którą cechuje natchnienie wyrywające aktora społecznego $z$ codzienności i sprawiające, że jest on gotowy do radykalnych decyzji i poświęceń. Taka miłość, zdaniem Giddensa, jest „zjawiskiem dość uniwersalnym” (s. 53) kulturowo, a w społeczeństwach zachodnich, zwłaszcza u mężczyzn, występuje od niepamiętnych czasów, często realizując się $\mathrm{w}$ postaci seksu pozamałżeńskiego.

Specyficzna kulturowo jest natomiast pojawiająca się później w historii kultury europejskiej miłość romantyczna. Polega ona na założeniu, że istnieje „możliwość trwałej więzi uczuciowej opartej wyłącznie na relacji między dwojgiem ludzi" (s. 10). Jej pojawienie się wnosi do życia jednostki ideę narracji opowiadania historii miłosnej, w której Ja i druga osoba stają się częścią narracji osobistej (s. 54-55) i która zakłada pewien rodzaj autorefleksji. U źródeł powstania tej odmiany więzi leży rozpoznanie drugiej osoby jako wyjątkowej i jej idealizacja - modelowa miłość romantyczna to miłość od pierwszego wejrzenia, intuicyjne rozpoznanie drugiej osoby (s. 55-56): „To ON/A!”.

Miłości romantycznej nieodłącznie towarzyszy intymność, która zakłada „duchowe porozumienie o charakterze dopełnienia” (s. 61). Podobnie jak $\mathrm{w}$ amour passion $\mathrm{w}$ wypadku miłości romantycznej pojawia się oczarowanie (silna projekcyjna identyfikacja $z$ obiektem miłości w pierwszym jej etapie), ale zostaje ono wpisane $\mathrm{w}$ wątek poszukiwania, podczas którego „tożsamość jednostki musi zostać odkryta przez drugą osobę i w niej odnaleźć własne potwierdzenie" (s. 62) Poczucie jedności z drugą osobą wzmacniają przy tym tradycyjne różnice między męskością a kobiecością, definiowanymi jako dwa przeciwstawne syndromy postaw i zachowań (s. 79). Docelowym etapem miłości romantycznej jest małżeństwo, przy czym „zwieńczeniem kobiecych marzeń o miłości romantycznej okazywała się zazwyczaj ponura rzeczywistość podległości panu domu" (s. 80).

Wreszcie trzeci i obecnie rozwijający się model więzi intymnej to miłość współbieżna. Jej warunkiem jest pojawienie się „plastycznej seksualności”, czyli uwolnienie seksu od wymogu reprodukcji oraz władzy męskiego sposobu widzenia doświadczenia seksualnego, a także upodobnienie się biografii seksualnych mężczyzn i kobiet (zwłaszcza jeśli chodzi o seks w związkach przedmałżeńskich) i depenalizacja zachowań dawniej potępianych (np. stosunków homoseksualnych czy masturbacji). Zasadniczą cechą miłości współbieżnej jest (a) jej „czynny” charakter (większa aktywność partnerów w miejsce dość biernego realizowania jednolitego wzoru kulturowego zgodnie z zasadą ,jakoś to będzie” i „tak musi być”) oraz (b) warunkowość (kłóci się ona $z$ „tylko” i „na 
zawsze” miłości romantycznej, istnieje „aż do odwołania” — czyli do momentu, w którym obie strony uznają, że nie czerpią już ze związku wystarczająco wiele korzyści), a przede wszystkim (c) jej kształt „refleksyjnego przedsięwzięcia” i podstawowy wymóg jej zaistnienia, jakim jest pełne „otwarcie się na drugą osobę" (s. 80).

Giddens definiuje zatem model miłości zyskujący dziś w jego opinii dominację tak, jak definiuje go spora część poradników: jako „otwarcie się” przed partnerem/partnerką i wspólne refleksyjne przepracowywanie swoich słabości. Kwintesencją miłości współbieżnej jest uczynienie „refleksyjnym przedsięwzięciem" zdolności doświadczania i dawania satysfakcji seksualnej, kształtowanej $z$ wykorzystaniem wielu źródeł informacji, porad oraz szkoleń i mającej zapewnić zadowolenie z seksu obu stronom związku (s. 81). Dla miłości współbieżnej charakterystyczne jest już nie małżeństwo, lecz bycie ze sobą w czystej relacji. Pojęcie to, dziś będące już symbolem koncepcji wyłożonej w Przemianach intymności, odnosi się do „[...] sytuacji, w których jednostki wchodzą w związek dla niego samego, czyli dla tego, co każda $z$ nich może wynieść $z$ trwałej więzi z drugą osobą” i trwających dopóty dopóki „obie strony czepią z niej dość satysfakcji, by chcieć ją utrzymywać. Niegdyś dla większości «normalnych» ludzi tym, co łączyło miłość i seksualność, było małżeństwo, ale dziś w coraz większym stopniu jest to czysta relacja. Dla większości, chociaż nie dla wszystkich grup, małżeństwo upodabnia się formalnie do czystej relacji” (s. 75-76).

Wszelkie związki oparte na modelu czystej relacji „opierają się na niewypowiedzianym «roboczym kontrakcie», który może zostać zakwestionowany przez dowolną stronę, kiedy uzna, że jest wykorzystywana lub krzywdzona" (s. 226). Ów zawsze renegocjowalny „kontrakt” to „narzędzie ustawowe”, stanowiące podstawę do ciągłej dyskusji nad związkiem (s. 226-227).

Czysta relacja to nie tylko pewne socjologiczne pojęcie, ale i fundament ogólniejszego, zdaniem Giddensa, wcielanego dziś w życie projektu zmiany społecznej:

„Niektórzy są zdania, że intymność może być duszna i przytłaczająca, i taka rzeczywiście jest, jeśli rozumieć ją jako żądanie nieprzerwanej bliskości emocjonalnej. Jednakże zdefiniowana jako więź emocjonalna na warunkach ustalonych przez równych partnerów ujawnia zupełnie inne oblicze. Intymność oznacza całkowitą demokratyzację relacji międzyludzkich, odpowiadającą demokracji w sferze publicznej. Ma to swoje dalsze konsekwencje. Przemiana sfery intymnej może podważyć nowoczesne instytucje jako takie, bo świat społeczny, w którym spełnienie uczuciowe zastąpiłoby dążenie do maksymalizacji zysku gospodarczego, bardzo różniłby się od tego, który znamy" (s. 11-12).

Taka właśnie demokracja sfery prywatnej „jest dziś nie tylko projektem, ale realną właściwością życia osobistego, który ujawnia się w czystej relacji" (s. 217). Czysta relacja jest zatem dla Giddensa czynnikiem wywołującym w życiu prywatnym rewolucję, za sprawą której ma dojść do ogólnej „demokratyzacji życia osobistego". Ma ona polegać na wprowadzeniu do życia jednostki 
autonomii, a także umiejętności zachowania granic osobistych, niezbędnych do prawidłowego funkcjonowania związków (s. 222).

Giddens usiłuje więc podsumować w swojej pracy wiele różnych trendów kulturowych naraz: przemiany $\mathrm{w}$ modelach życia rodzinnego, sposobach rozumienia miłości, seksualności i obyczajowości, kobiecości i męskości. Jest to zadanie wymagające i ryzykowne. Im bardziej wszechobejmujący jest schemat, tym większe ryzyko, że zostanie poddany krytyce opartej na szczegółowych analizach poszczególnych sfer życia społecznego lub epok historycznych, których dotyczy ${ }^{4}$. Oczywiście, uprawianie nauki polega na tworzeniu pewnych uogólnień. Jednak nawet $\mathrm{w}$ przypadku, gdy naczelnym zadaniem jest stworzenie generalnego schematu zmiany społecznej, warto: (a) zachować możliwość analizy stopnia zaawansowania przemian, a także uniknąć ekstrapolowania trendów lub zjawisk typowych dla środowiska, z którego pochodzi autor, na wszystkie środowiska lub klasy społeczne; (b) brać pod uwagę różnicę między dyskursem źródeł, na jakich bazuje autor, a dyskursem socjologicznym; (c) stworzyć szansę późniejszego uszczegółowienia analizy poprzez opis procesów i etapów przemian oraz dialektyki zmiany i oporu przeciw zmianie, towarzyszących zmianie napięć i konfliktów.

\section{PORADNIKI A INTYMNOŚĆ \\ SPECYFIKA I MANKAMENTY DYSKURSU TERAPEUTYCZNEGO JAKO ŹRÓDŁA SOCJOLOGICZNEGO}

Sam fakt przemian intymności nie podlega dyskusji. Dyskusyjny jest jednak ich zakres. Choć Giddens obwieszcza dokonywanie się podskórnej rewolucji w związkach i rozpowszechnianie się czystych relacji, nie dostarcza zbyt wielu dowodów na to, a czasem wręcz sam - przytaczając wyniki badań podaje $\mathrm{w}$ wątpliwość zakres ich rozpowszechnienia. Ten problem wynika, jak się wydaje, ze specyfiki źródeł, na których została oparta praca i sposobu ich interpretowania.

Pierwsze pytanie w tym kontekście dotyczy tego, w jakiej mierze obraz związków i ich przyszłości zawarty w poradnikach może stanowić podstawę do wnioskowania na temat faktycznego kształtu codzienności w związkach intymnych. Giddens zdaje sobie sprawę z ograniczeń płynących z wyboru takich a nie innych materiałów:

„W tym omówieniu będę się często kierował [...] opisami terapii i sugestiami zawartymi $\mathrm{w}$ rozmaitych poradnikach. Nie powołuję się na nie jako źródła, które trafnie zdają sprawę ze zmian zachodzących w życiu osobistym, zresztą większość to zasadniczo praktyczne instrukcje. Odwołuję się do nich, bo moim

\footnotetext{
${ }^{4}$ Dobrym przykładem - w obszarze analiz życia codziennego - mogą być trwające od lat w socjologii niemieckiej i holenderskiej dyskusje wokół koncepcji procesu cywilizacyjnego Norberta Eliasa (Duerr 1988, 1997; Schröter 1997; Wouters 1999; Hinz 2002).
} 
zdaniem stanowią one wyraz refleksyjności, której są zapisem i której nadają formę" (s. 82).

Wielokrotnie jednak wydaje się, że traktuje je właśnie jako trafny obraz faktycznych zmian (zob. np. s. 75-76, por. krytyczną analizę Jamieson 1999, s. 480-481).

Oczywiście można założyć, że jest to po prostu zabieg retoryczny, mający na celu wyeksponowanie kierunku zachodzących zmian. Możliwość takiej podwójnej interpretacji wynika z dwuznaczności Przemian intymności. Niekiedy bowiem Giddens traktuje czystą relację jako idealny, ale jednak faktycznie funkcjonujący model dzisiejszych związków, który zaczyna dominować w obszarze relacji intymnych (np. s. 75-76), gdzie indziej zaś opisuje ją jako nie istniejący i niemożliwy do osiągnięcia typ idealny („prototyp relacji osobistej”, s. 184), ku któremu zmierzają związki, czy wręcz zaledwie jako „ramy etyczne” dla związków (s. 238).

Można też zastanawiać się, jak pogodzić nieliczne fragmenty, w których Giddens ostrzega przed niedocenianiem barier uniemożliwiających wielu kobietom osiągnięcie równości zarówno w sferze publicznej, jak i prywatnej (s. 159, 186-187), z tymi, w których subtelne procesy sprawowania władzy i walki o władzę w związku zostają zupełnie pominięte (por. Jamieson 1999, s. 482, 484-485). Nie do końca również jest jasne, jak mają się do fragmentów mówiących o czystej relacji jako fakcie empirycznym wyniki przytaczanych przez Giddensa (2006, s. 63-79) badań empirycznych autorstwa Sharon Thompson i Lilian Rubin, które pokazują, jak spore nadal są różnice między płciami w zakresie władzy, seksualności i traktowania związku intymnego.

Podobne napięcia pokazują współczesne badania na temat problematycznej sytuacji dużej części samotnych kobiet, którym na wiele subtelnych sposobów daje się do zrozumienia, że nie spełniają społecznych czy rodzinnych oczekiwań, które spotykają się z osamotnieniem i niezrozumieniem ze strony dawnych koleżanek i - przede wszystkim - doświadczają konsekwencji rozdarcia między dążeniem do niezależności a dotkliwym poczuciem braku partnera (np. Kaufmann 2002; Jewdokimow, Garncarek 2008; Żurek 2008, s. 270-271). W dużo mniejszym stopniu dotyczy to mężczyzn-kawalerów.

Możemy życzliwie założyć, że Giddens poświęcił tym kwestiom niewiele uwagi, ponieważ zamierzał wyeksponować kierunek zachodzących zmian i czystą relację jako typ idealny. Nawet w takim wypadku warto jednak zadać pytanie: czy koncentracja na poradnikach nie prowadzi do tracenia $z$ oczu tego, co w związkach mało refleksyjne, oraz do dynamicznego przechodzenia spraw na początkowych etapach tworzenia związku intymnego poddawanych refleksji w bezwładne, stabilne role i przyzwyczajenia, czasem tylko mające znów szansę stać się obiektem refleksji. Brak tego typu analizy jest szczególnie zaskakujący, jeśli weźmiemy pod uwagę najważniejszą pracę Giddensa Stanowienie spoteczeństwa. Zaprezentowany tam „stratyfikacyjny model jednostki” (Giddens 
2003, s. 41-43) składał się z trzech współgrających ze sobą pięter: motywów nieświadomych, świadomości praktycznej i świadomości dyskursywnej. Szczególne znaczenie przypisywał wówczas autor świadomości praktycznej, którą określał jako „główny temat tej książki” (Giddens 2003, s. 21), tak definiując relacje między nią a refleksyjnością:

„To, co podmiot wie o tym, co czyni i dlaczego tak czyni — jego refleksyjność uwikłane jest w świadomość praktyczną. Na świadomość praktyczną składa się wszystko, co aktorzy wiedzą o tym, jak "poruszać się" na scenie społecznej, ale czego nie potrafią wyrazić dyskursywnie" (Giddens 2003, s. 21).

Jako „zasadniczy koncept teorii strukturacji” Giddens (2003, s. 22) określił wówczas rutynizację. W Przemianach intymności, podobnie zresztą jak w pracy Nowoczesność i tożsamość (Giddens 2001), to, co dawniej kluczowe - świadomość praktyczna - teraz staje się drugorzędne, całkowicie przyćmione przez świadomość dyskursywną oraz nieświadome motywy i konflikty powstałe na tle psychologicznym (s. 166-168). Choć Giddens przypomina, że „całe życie społeczne jest w znacznej mierze zrutynizowane" (s. 90), wzory zachowań i przyzwyczajenia dotyczące rozmaitych banalnych czynności życia codziennego są dla niego stosunkowo łatwo modyfikowalnymi, banalnymi elementami codzienności i cechami w dużej mierze indywidualnymi. Jedyne szerzej interesujące go formy rutynizacji dotyczące relacji intymnych to omawiane szeroko w literaturze terapeutycznej „kompulsywne zachowania przymusowe” oraz „uzależnienia” (s. 91 i nast.), stanowiące przeszkodę dla czystej relacji, bo negujące wolność osobistą i kontrolę nad własnym życiem.

Tymczasem osoby tworzące związek wnoszą do niego setki drobnych wzorów zachowania i przyzwyczajeń, które muszą następnie „dotrzeć”, a więc wpleść podobieństwa i różnice $\mathrm{w}$ jakiś sprawnie funkcjonujący mechanizm (por. Kaufmann 1994). Co więcej, to właśnie w wyniku obserwacji problemów powstających $\mathrm{w}$ procesie tworzenia wspólnych rytmów codzienności możemy powiedzieć, jakie zmiany zachodzą w modelach intymności i jakie różne modele bycia razem możemy dziś zaobserwować. Dawniej, w małżeństwie zawieranym „na zawsze” (choć niekoniecznie po długiej znajomości) oraz w sytuacji silnej władzy hierarchicznej trzeba było (a dotyczyło to przede wszystkim kobiet) wpasować się w wiele sztywnych form zachowań, w małym stopniu podlegających indywidualnym definicjom. Obiad jedzony zawsze o $13.00 \mathrm{w}$ wielu związkach bywał rytuałem, do tego społecznie zalegalizowanym. Jeśli dziś dokonują się rewolucje $\mathrm{w}$ związkach intymnych, to należy ich szukać między innymi w utracie oczywistości tego typu rytuałów. Trudno jednak zakładać, że jedynym lub dominującym sposobem negocjowania przez partnerów wspólnych definicji rzeczywistości i życia w związku staje się „pełne otwarcie się na drugą osobę", racjonalna dyskusja, daleko posunięte zwierzanie się, refleksja nad sobą i nad potrzebami drugiej osoby. Takie założenie oznacza zarówno przecenienie rozmiarów czystej refleksyjności w życiu codziennym, jak i poświęcenie 
zbyt mało uwagi różnym subtelnym mechanizmom władzy w związkach intymnych.

Dyskusyjną kwestią w pracy Giddensa jest zatem relacja między dyskursem poradników a socjologicznymi modelami przemian kulturowych oraz wiedzy ludzkiej (por. Jamieson 1999, s. 480-481). Wydaje się, że nie tylko traktuje on literaturę terapeutyczną jako wskaźnik zmian w związkach (co można ewentualnie obronić jako zabieg mający na celu ilustrację trendów), ale też utożsamia wiele $z$ ich założeń z założeniami analizy socjologicznej. Tymczasem wątpliwe jest, w jakim stopniu presupozycje poradników - na przykład uznanie intymności za synonim „pełnego otwarcia się przed partnerem” — nadają się do tego, by stworzyć wieloaspektowy opis socjologiczny.

Przykładem niech będzie analiza „uzależnień” od seksu lub związku. Zauważając, że są one „reakcją obronną i ucieczkową” (s. 96) oraz sposobem „kontroli jednostki nad elementami jej codziennego życia, a także nad samą sobą", Giddens przyjmuje następnie w całości wyłącznie punkt widzenia omawianych poradników. Więzi oparte na uzależnieniu (s. 113):

„1) nie pozwalają obserwować siebie samego i drugiej osoby, podczas gdy takie przyglądanie się sobie i partnerowi ma żywotne znaczenie dla czystej relacji, 2) lokują tożsamość jednostki bądź to w osobie partnera, bądź w utrwalonych rutynach, 3) nie pozwalają otworzyć się na drugą osobę, podczas gdy właśnie na takim otwarciu polega intymność, 4) sprzyjają nieegalitarnej segregacji ról związanych z płcią i praktyk seksualnych".

Tożsamość osób uzależnionych od związku „miesza się z tożsamością partnera”, podczas gdy „intymność nie polega na zlaniu się z drugą osobą, ale na poznaniu jej i otwarciu się przed nią" (s. 117) i jasnym określeniu granic między partnerami. „Naiwne mrzonki psychologii?” — pyta Giddens (s. 119) — „Być może, przynajmniej w pewnej mierze”. Jak jednak zaraz dodaje: „Odzwierciedlają one pewne tendencje rozwoju relacji intymnych, które staram się w tej książce dokumentować. Czyż można nie dostrzec w nich dowodu i programu demokratyzacji życia codziennego?"

Można jeśli — podobnie jak Lynn Jamieson (1999, s. 480) — założy się, że:

„[...] natura dopasowania między ideologicznym opowiadaniem a codziennymi relacjami nie jest prosta. Możliwa jest na przykład sytuacja, w której dyskurs «ekspertów od związków» zainspirował codzienne rozmowy, podczas gdy parametry określające praktyki życia codziennego modyfikowane są przez inne czynniki. Tego typu kwestie — komentuje Jamieson — nie zostały w Przemianach intymności w pełni rozwinięte. Mimo odwołania się do refleksyjnego powiązania między swoją praca, kulturą popularną oraz dyskursem terapeutycznym Giddens stosunkowo bezkrytycznie czerpie z tego ostatniego, traktując go jako dokumentację oraz symptom zmiany jednostkowej i społecznej [...]. Nie jest [więc] niespodzianką, że jego opis «czystej relacji» dobrze pasuje do dyskursu terapeutycznego, który wysoką wartość przypisuje odsłanianiu Ja w trakcie terapii oraz w związkach, które terapia ma nadzieję uleczyć". 
Trudno nie przyznać Jamieson racji. Giddens bowiem nie tyle skupia się na tym, przed czym uciekają osoby „uzależniające się” od partnera lub związków, jak próbują sobie $z$ tym radzić i jakie strukturalne problemy lub sprzeczności się za tym kryją, ile traktuje ten problem wyłącznie albo jako kwestię terapeutyczną, albo też jako wynik problemów psychologicznych. W pierwszym wypadku analizuje terapeutyczne zalecenia, jakimi są głębsze zaangażowanie się w czystą relację, polegające na „otwarciu się”, lepsze „obserwowanie siebie” oraz dokładniejsze wyznaczenie „granic autonomii partnerów". W drugim wypadku - zauważa wiele sprzeczności i napięć targających związkami mogącymi pretendować do statusu (lub chociaż prekursorów) czystych relacji, jednak ugruntowuje je niemal wyłącznie psychologicznie. Wynikają one, jak przekonuje (s. 157-158), ze sprzeczności charakterologicznych między płciami, czemu winna jest przede wszystkim przewaga matki $\mathrm{w}$ procesie wychowawczym i nieświadome uwielbienie dla niej ze strony synów, a także „kulejąca narracja tożsamościowa” u tych ostatnich. Dlatego „niedopasowanie” mężczyzn do zmian, jakie promują kobiety, pionierki czystej relacji, jest rezultatem dążenia do odreagowania „wypartej zależności emocjonalnej od kobiet” (s. 183) i skutkuje obroną swoich dotychczasowych przywilejów. Dodatkowy kłopot stanowi przy tym „utrata oczywistości fallusa” (s. 183) i to, że „dla kobiet, przynajmniej na poziomie poznawczym, mężczyźni stali się niczym więcej, jak tylko dysfunkcjonalnym dodatkiem do męskiego organu płciowego" (s. 183).

Nawet jeśli pominie się dyskusyjność tego typu tez, to uderza skromne znaczenie przypisywane konfliktom innym niż te oparte na relacjach rodzic-dziecko. W największym uproszczeniu mógłby to być choćby konflikt między chęcią zbierania wciąż nowych doświadczeń lub strachem przed oparciem swojego życia na jednej, emocjonalnej decyzji a równoczesnym poszukiwaniem potwierdzenia Ja i chęcią ucieczki w jedną, głęboką relację emocjonalną, obliczoną na całe życie. Lynn Jamieson $(1999$, s. 486) idzie w swoich analizach w jeszcze innym kierunku: nietrwałość związków w wielu wypadkach wydaje się nie efektem balansowania między normą zaufania a permanentną odwoływalnością związku, jak sądzi Giddens, lecz efektem napięcia między rosnącym kulturowym naciskiem na intymność, równość i wzajemność a strukturalnym wsparciem dla ciągłości nierówności płciowych, utrudniających realizację tych wartości.

Wskazałem tu różne rodzaje wątpliwości, jakie budzi tekst Giddensa, wynikające przede wszystkim z przyjętej przez niego metody analizy opartej na dyskursie terapeutycznym. Próbując wskazać sposoby przezwyciężenia tych problemów, pragnę teraz poświęcić uwagę pracom domowym, będącym nie tylko dobrym wskaźnikiem faktycznych zmian w relacjach między płciami i związkach intymnych, ale i dobrym polem dla ilustracji ambiwalencji i konfliktów towarzyszących tym przemianom. 


\section{CODZIENNOŚĆ INTYMNOŚCI \\ PRACE DOMOWE JAKO POLIGON DLA OBSERWACJI PRZEMIAN CHARAKTERU ZWIĄZKÓW}

Praca domowa kobiet przyciągnęła uwagę nauk społecznych w latach siedemdziesiątych, a więc wówczas gdy jej wykonywanie przez kobiety zaczęło być mniej oczywiste (Bock, Duden 2000, s. 30; Künzler 1994, s. 19). Wówczas też stała się powszechnym tematem różnych badań sondażowych, w których próbowano ustalić, jakie czynniki determinują podział i wykonywanie pewnych prac domowych oraz $\mathrm{w}$ jakim stopniu przemiany kulturowe lat sześćdziesiątych zachwiały tradycyjnym podziałem ról. Większość badań, jakie na ten temat wykonano (zob. Sanchez 1994; Künzler 1994), albo prowadzona była w duchu rozmaitych odmian teorii racjonalnego wyboru (ressources theory, new home economics, time-avalibility theory), albo też stanowiła rodzaj sondażu opinii na temat równouprawnienia. Jak pisze Jan Künzler (1994, s. 65-66, 69-70, 88 i nast.), wyniki badań na temat udziału mężczyzn w pracach domowych przeciwstawiają się „zarówno zdrowemu rozsądkowi, jak i hipotezom i prognozom” zastosowanych modeli. Średni udział mężczyzn w pracach domowych od lat siedemdziesiątych do połowy lat dziewięćdziesiątych niemal nie zmienił się w Stanach Zjednoczonych i wynosi nieco ponad 9 godzin tygodniowo. Podobną ilość czasu spędzali mężczyźni na pracach domowych w Niemczech i tu także nie zaszły W omawianym okresie jakieś większe zmiany (Künzler 1994, s. 26-43; por. Burkart, Koppetsch 1999, s. 203-204); mężczyźni szczególnie rzadko angażowali się $\mathrm{w}$ pranie, następnie sprzątanie, gotowanie i prasowanie, $\mathrm{w}$ domu wykonywali przede wszystkim naprawy, zajmowali się samochodem. Z kolei praca zawodowa kobiety czy lepsze wykształcenie nie tyle zwiększały udział mężczyzny w pracach domowych, ile najczęściej raczej zmuszały kobiety do redukcji swojego zaangażowania w dom (Künzler 1994, s. 67). W omawianym okresie zmieniły się jedynie opinie mężczyzn i kobiet na temat równouprawnienia w dziedzinie prac domowych (Künzler 1994, s. 21). Związek między tymi opiniami a faktycznym uczestnictwem w pracach domowych jest jednak dość problematyczny - $\mathrm{w}$ niektórych badaniach jest on widoczny, w innych w ogóle nie występuje (Künzler 1994, s. 107-108).

Podobnie jest w badaniach polskich (Budrowska 2005; Szczepańska 2006), $z$ których wynika, że osobą odpowiedzialną $\mathrm{w}$ domu za pranie jest $1-8 \%$ mężczyzn ${ }^{5}$, za prasowanie - 4-8\% mężczyzn, przygotowywanie obiadu 3-7\%, czyszczenie kuchenki i zlewu -3-13\%. Blisko 89\% mężczyzn zajmuje się za to sprawami związanymi z samochodem, a 25-60\% wyrzucaniem śmieci. Przez ostatnie dwadzieścia lat udział mężczyzn w pracach domowych nieznacznie wzrósł i można szacować, że obecnie jest co najmniej dwa razy mniejszy

${ }^{5}$ Rozbieżności wynikają głównie z tego, czy opieramy się na deklaracjach mężczyzn czy kobiet i jak traktujemy deklarację „wykonujemy to wspólnie”. 
niż udział kobiet (nie licząc jednak opieki nad dziećmi, którą sprawują w $90 \%$ kobiety), a nie — jak to było w 1984 r. — trzy razy (Budrowska 2005, s. 13, 16). Są to liczby zbliżone do tych obserwowanych w Danii czy Francji.

Podobnie jak w krajach zachodnich, zmienia się w Polsce sfera przekonań. Według jednego z badań z 2003 r., blisko 90\% kobiet chciałoby, aby „W takim samym stopniu kobieta jak i mężczyzna zajmowali się domem i dziećmi" (Budrowska 2005, s. 16). Na pytanie o to, czy popiera się „równy podział obowiązków", w 2002 r. twierdząco odpowiedziała ponad połowa Polaków, podczas gdy jeszcze w 1993 r. była to $1 / 3$ (Titkow 2006, s. 228-229). Jednak kiedy zapytamy wprost o to, czy w danym związku ten model jest realizowany, to okaże się, że dotyczy to $25 \%$ par. Nietrudno zgadnąć, że nadal nie jest to liczba par o faktycznie wyrównanym budżecie czasu, bo „równy podział obowiązków” niemal w żadnej parze nie oznacza, by kobieta nie pracowała w domu więcej niż mężczyzna.

To, co z punktu widzenia niektórych wersji teorii racjonalnego wyboru w pierwszej chwili może się wydawać zagadką, można próbować wyjaśniać sięgając do wyników badań panelowych oraz jakościowych. Oto niektóre z ich ustaleń:

(a) Nierówne rozłożenie obowiązków jest zdecydowanie mniejsze na początku związku i rośnie z czasem, a obciążenie kobiety wzrasta wtedy, gdy pojawia się dziecko (Künzler 1994, s. 108 i nast.; por. Kaufmann 1994).

(b) Nietradycyjny i niestandardowy sposób wykonywania i dzielenia obowiązków domowych $\mathrm{w}$ wysokim stopniu zależy od tego, czy badany miał okazję mieszkać poza domem rodzinnym przed zamieszkaniem z partnerem/partnerką, czy też przeniósł się z domu rodzinnego prosto do domu małżeńskiego (Künzler 1994, s. 116-117; por. Kaufmann 1994).

(c) Istnieją czynności, które są szczególnie odstręczające dla mężczyzn, niezależnie od tego, jak wiele kompetencji trzeba nabyć, aby je wykonać (Künzler 1994, s. 117; Burkart, Koppetsch 1999, s. 210-213), na przykład zajęcia związane $z$ użyciem wody (wyjątek to mycie auta) oraz ubraniami, podczas gdy bardziej lubiane są czynności wykonywane poza domem (większe zakupy, wynoszenie śmieci, podlewanie ogrodu itp.), wymagające użycia siły, wykonywane „z grubsza” (np. mężczyzna czyści z grubsza, a kobieta szoruje potem szczegóły) i niecodzienne (np. grill w weekend albo wyjście $z$ dzieckiem do kina).

(d) Mężczyźni dysponują szeregiem wymówek, jeśli chodzi o ich zaangażowanie $\mathrm{w}$ domu - podczas gdy prace domowe kobiety są zwykle jej obowiązkiem, którego niewykonanie często oznacza zachwianie porządku dnia codziennego i wywołuje co najmniej zdziwienie; pomoc ze strony mężczyzny wymaga każdorazowo uzasadnienia, a często też rewanżu (Künzler 1994, s. 121; Duch-Krzysztoszek 2007, s. 159-162; Burkart, Koppetsch 1999).

(e) Wiele z czynności domowych sprawia kobietom przyjemność albo są uważane, także przez same kobiety, za kobiecy obowiązek lub czynność, która musi zostać wykonana za wszelką cenę — ostateczny podział ról zależy więc 
często zarówno od posiadanych kompetencji w zakresie prac domowych, jak i od zinternalizowanych wymagań w zakresie czystości i porządku oraz standardu wykonania domowych obowiązków. Średnio rzecz biorąc, kobiety nabywają więcej przyzwyczajeń i standardów związanych z domowym porządkiem niż mężczyźni, co każe im nieraz wykonać czynności, które mężczyźnie nie wydają się konieczne, przynajmniej dopóty dopóki po długim czasie faktycznie nie zostaną wykonane (Kaufmann 1994, 1999, 2004; por. Baxter 2000; Doucet 2001). Kobiety są więc często znakomitymi wspólniczkami tradycyjnego układu ról płciowych, podtrzymującymi go po części wspólnie z mężczyznami. Przytoczmy przykłady z badań:

Respondentka: To znaczy mogłabym nie sprzątać przez tydzień, nie włączać odkurzacza [...]. Przecież nikt tam nie chodzi w kaloszach, prawda no a to, że ja mam taką potrzebę, że przychodzę z pracy i jak ten automat muszę, nie wiem, grzać zupę albo robić następną, czy przygotować obiad, no to „Nie, no to zjemy kanapki” - to są takie odpowiedzi, albo „Po co dzisiaj odkurzasz? Musisz teraz odkurzać? Stało się coś? - Nie. Wysypało się? - Nie”, „No nie, ale ja potrzebuję odkurzyć”, „Ale przecież możesz to zrobić jutro” i to jest właśnie postrzeganie domu przez mężczyznę. No nie, mogę, pewnie że mogę jutro, ale tą metodą to ja mogę trzy dni sobie odpoczywać (Budrowska 2005, s. 15).

Ankieter: Czy starasz się jej [żonie] przedstawić swoją wizję domu? Domu jako azylu?

Respondent: Tak, czasami mówię jej, że i tak się pobrudzi. Po co to sprzątać. Będzie pobrudzone. Lepiej to zrobić może rzadziej. Albo znowu staram się odwrócić jej uwagę. Mówię jej, że: „Zostawmy to... Wyjdźmy gdzieś...” No albo sam gdzieś wychodzę... (Budrowska 2005, s. 15).

(f) Choć przekonania o potrzebie równouprawnienia są coraz bardziej rozpowszechnione, a w środowiskach akademicko-inteligenckich przyjmowane jako oczywistość, często rozmijają się one $z$ faktycznym podziałem obowiązków domowych. Jak pokazują studia jakościowe we Francji (Kaufmann 1994, 1999), Niemczech (Burkart, Koppetsch 1999) i Polsce (Duch-Krzystoszek 2007), konieczne jest uwzględnienie różnicy między powierzchownym akceptowaniem pewnych dyskursów a faktycznie zakorzenionymi w codzienności i przyzwyczajeniach schematami działania (czym zresztą interesował się Giddens w swoich wcześniejszych pracach). Wiąże się to ogólnie z problemem wyjaśniania zachowań w prostym schemacie wartości-działania, zwłaszcza gdy wartości operacjonalizowane są po prostu jako zestawienia procentowe $z$ odpowiedzi na hasłowe, ogólne pytania, których treść odpowiada dyskursom społecznie dziś już pochwalanym i akceptowanym (por. Marody 1996).

Jak widać, ogólny schemat podziału zadań (męskie - na zewnątrz, suche, wymagające siły i jednorazowe, wyjątkowe i na pokaz; kobiece - we wnętrzu, mokre, wymagające precyzji i czasu, codzienne i niewidoczne) chwilami przypomina wręcz antropologiczne dualizmy, występujące w społeczeństwach przednowoczesnych (por. Bourdieu 2004), wskazując na wyjątkowo silne za- 
korzenienie pewnych wzorów zachowania w długotrwałej pamięci społecznej. Te pokłady wiedzy zmieniają się znacznie wolniej niż leżące płytko przekonania deklaratywne oraz racjonalizacje, a nieraz zdarza się, że dochodzi między nimi do różnych konfliktów.

Niezwykle interesujący jest $\mathrm{w}$ związku $\mathrm{z}$ tym proces budowania par intymnych przez osoby młode, zwłaszcza dysponujące wysokim kapitałem kulturowym, a więc mające największe szanse i predyspozycje, by zmierzać w kierunku Giddensowskiej czystej relacji. Wiele z tych par świadomie zwraca się przeciwko nierównemu podziałowi obowiązków (Kaufmann 1994; Burkart, Koppetsch 1999). Wyraża się to już w samym odwlekaniu momentu stworzenia wspólnego miejsca zamieszkania „z prawdziwego zdarzenia”. Choć młode francuskie pary posiadają na przykład ponadprzeciętnie dużo sprzętu muzycznego, meblem, który występuje $\mathrm{w}$ ich gospodarstwach znacznie rzadziej niż średnio we francuskich domach, jest pralka - przez wiele par postrzegana jako jaskrawy symbol małżeńskości (Kaufmann 1994, s. 82). Przedmioty potrafią szybko zestalić relacje między osobami tworzącymi wspólny dom i wyznaczyć rutyny, z których ciężko się już potem uwolnić (Schmidt F. 2010). Pranie często robi się więc $\mathrm{w}$ weekend $\mathrm{u}$ rodziców albo $\mathrm{w}$ którejś $\mathrm{z}$ licznych pralni. Wiele par podejmuje też próbę osobnego prania swoich własnych rzeczy, często kończącą się niepowodzeniem i przejęciem roli piorącej przez dziewczynę. Wielokrotnie młodzi ludzie opowiadają o tym, że sami zaskoczeni byli tym, jak bardzo zaczęło im zależeć na wykonywaniu wcześniej zaniedbywanych prac domowych, gdy zamieszkali wspólnie: „mieszkając osobno bylibyśmy mniej porządni” (Kaufmann 1994, s. 75-76).

W młodych francuskich parach, zwłaszcza jednak tych o wyższym kapitale kulturowym, początkowy okres jest też nie tylko testowaniem instytucji wspólnego mieszkania, a przyszłościowo - małżeństwa, ale i testowaniem partnera, także na polu emocjonalnym i seksualnym (Kaufmann 1994, s. 91). I także pod tym względem bez wątpienia tego rodzaju pary mają pewne cechy czystej relacji. Nie oznacza to jednak, że spełniają one inny jej warunek, jakim jest „pełna otwartość”, zwierzanie się partnerowi z wszystkich trosk, wątpliwości oraz słabości. Wiele z reguł dotyczących wspólnego życia ustala się w praktyce, milcząco, krok po kroku, co czasem nawet zaskakuje tworzące parę osoby, tak że potem mają spore problemy z ustaleniem, kiedy zdecydowali o jakimś szczególe swojej codzienności. Nieraz też refleksja przychodzi dopiero później. Jak mówi jedna $\mathrm{z}$ respondentek:

„To powinniśmy byli zrobić, jak byliśmy młodsi. Wtedy kiedy się pobraliśmy, w tamtym momencie powinniśmy coś przedsięwziąć. Potem to już jest za późno: jak człowiek się przyzwyczai do określonych rzeczy, to potem podąża ciągle za tą samą rutyną [...]" (Kaufmann 1994, s. 74).

Także w związkach intymnych osób młodych dochodzi zatem często do współistnienia nierówności w faktycznym podziale obowiązków oraz konstru- 
owania obrazu siebie jako nowoczesnej pary wyznającej ideał równouprawnienia. Za Jamieson (1999, s. 485) warto zaznaczyć, że nie chodzi o to, by „negować znaczenie, jakie ma w wielu związkach dla poczucia intymności przekonanie, że jest się równym. Istnieje generalne założenie, uważane za oczywiste, że dobry związek będzie się cechował równością i intymnością. Chodzi raczej o zasugerowanie, że kreatywna energia używana jest do celów przykrywania, maskowania nierówności, a niekoniecznie ich podkopywania [...]". Istnieje wiele mniej lub bardziej świadomie stosowanych strategii służących partnerom do delegowania niechętnie wykonywanych czynności na drugą osobę oraz sposobów obrony przed takim delegowaniem (zob. Duch-Krzystoszek 2007, s. 162-167; Burkart, Koppetsch 1999), a jednocześnie — mnóstwo taktyk służących do podtrzymania obrazu siebie jako osoby nowoczesnej i tworzącej związek oparty na równouprawnieniu. W rezultacie ludzie próbują często wynajdywać różne sposoby radzenia sobie $z$ dysonansem, jaki wywołuje zwrócenie uwagi na faktyczny podział obowiązków (zob. Duch-Krzystoszek 2007, s. 49-50, 56 i in.; Burkart 2008, s. 264-66; Burkart, Koppetsch 1999; Kaufmann 1994).

Wszystko to nie znaczy, by należało z kolei negować dokonywanie się kulturowej zmiany w obszarze organizacji codzienności w związkach intymnych albo też traktować opisane przed chwilą zjawisko jako rodzaj „fałszywej świadomości” czy świadectwo tego, ,jak jest naprawdę”. To, że równość nie jest przez wielu praktykowana, ale większość przyjmuje ją jako coraz bardziej oczywistą regułę, jest bardzo istotnym novum, a być może także etapem na drodze do dalszej modyfikacji układu reguł obowiązujących w relacjach między płciami. Zachowanie par zmuszonych opowiadać o swoim podziale obowiązków osobie z zewnątrz (np. ankieterowi) jest bardzo wymowne. Mężczyźni, którzy przykładają się w jakimś widocznym stopniu do domowych obowiązków, nie opisują tych czynności w sposób neutralny, lecz przebija z ich słów duma, często prezentują się jak nowocześni bohaterowie. $Z$ kolei kobieta często, jak pokazuje studium Jeana-Claude'a Kaufmanna (1994, s. 176):

„[...] jest dumna, że ma takiego mężczyznę za partnera albo że jako takiego go prezentuje, tak $\dot{z} \mathrm{e}-\mathrm{w}$ razie pojawienia się pewnych wątpliwości - uwypukla jego, w gruncie rzeczy śmieszne, okazyjne odkurzanie i niedzielne przygotowywanie grilla. Mężczyźni, którzy mało co w domu robią, czują się w wywiadach bardzo nieswojo, jak gdyby byli winni naruszenia prawa i ogólnie uznanej moralności. Szukają więc nieporadnie okoliczności łagodzących i bronią się zawstydzeni, wciąż wspominając o marnych przykładach pomocy ze swojej strony. Ich żony, które w domu wszystko robią same (niezależnie od tego, czy są wyłącznie gospodyniami, czy też pracuja), czują się niekiedy jeszcze bardziej winne niż oni".

Występujący przy takich okazjach wysiłek argumentacyjny pokazuje, jak mocno nowe idee infiltrują sferę przekonań na temat tego, co jest społecznie legitymizowane. Choć w $90 \%$ domów pierze kobieta, pytanie w rodzaju „Czy pranie i zajmowanie się wypranymi rzeczami to zadanie kobiety?” 
w większości wywołuje niepokój i zakłopotanie (Kaufmann 1994, s. 176-177 i in.).

Podobny kłopot potrafi sprawić stworzenie spójnej narracji na temat powstania swojego związku i jego wyjątkowości. W modelu miłości romantycznej człowiek przełamuje bariery społeczne, konwenanse, ewentualny opór rodziny, ale swojej biografii nadaje sens dzięki przekonaniu, że: „Na świecie istnieje ta jedyna istota, która przeznaczona jest dla mnie i kiedy któregoś dnia ją spotkam, wtedy od razu będę wiedzieć, że to on/ona" (Kaufmann 2005, s. 317). To wyobrażenie sięga daleko w przeszłość, a zarazem jest niezwykle trwałe i dziś. Elementy klasycznej mitologii związku są nadal bardzo istotne dla wielu ludzi, łącznie $z$ tymi młodymi o wysokim kapitale kulturowym. Jednocześnie istnieje wiele par, które wkraczają w swoje związki małymi, bocznymi drzwiami, dopiero po fakcie rozpoznając, że „tam” właśnie rozpoczęła się ich historia. Mają one jednak problem $z$ opowiadaniem o tym osobom trzecim — „tak jakoś wciąż głupio nie być nadal choć trochę w zgodzie $z$ modelem romantycznym” (Kaufmann 2005, s. 318-321). Historyczne modele więzi miłosnej przedstawione przez Giddensa ścierają się ze sobą, a przebieg tych starć jest obiektem wartym socjologicznego badania.

Wracając do obszaru prac domowych, warto zauważyć, że obok par, w których toczy się niezwykle interesująca codzienna walka z partnerem, spojrzeniem matki czy teściowej i z samym sobą, istnieją też pary o bardziej tradycyjnych oczekiwaniach. Niektóre $z$ nich nawet nie zauważają momentu, w którym ich porządek dnia codziennego i podział prac domowych został ustalony (Kaufmann 1994, s. 79 i in.; Burkart, Koppetsch 1999), są też one nieraz w dużej mierze odporne na infiltrację sfery swoich przekonań. Różnice te są w Przemianach intymności niemal całkowicie pominięte (por. Meuser 1998b) i zastapione uniwersalnym założeniem, że intymność jest tożsama z „otwartością”. „Osoba, która częściej zwierza się ze swoich uczuć i przeżyć przyjacielowi niż kochankowi, ma prawdopodobnie zastrzeżenia do swojego związku z tym ostatnim" - pisze Giddens (s. 167), podczas gdy w wielu środowiskach model intensywnego komunikowania się $\mathrm{w}$ pewnych zakresach nie partnerem, lecz bliskimi osobami tej samej płci jest nadal silny, niekiedy niepoddawany w ogóle refleksji i opiera się na modelu separacji światów kobiet i mężczyzn, dawniej jeszcze silniejszej (zob. Wouters 2004; Schmidt G. 2004). Nie ma też powodu, dla którego mielibyśmy zakładać, że jest to po prostu stadium przejściowe (na drodze do czystej relacji) lub ferować uniwersalne oceny i wyroki na temat jakości tego typu związków.

W świetle wszystkiego, co dotychczas powiedziano, model czystej relacji Giddensa wydaje się w pewnych aspektach nierealny nawet jako projekt etyczny.

„Model demokratyczny zakłada [...] — jak pisze Giddens (s. 230-231) — równość, której celem jest nie tyle kompletne zrównanie płci, ile uczciwie wyważony układ oparty na zasadzie autonomii. Efektem negocjacji byłby określony, 
zadowalający każdą ze stron, stan równowagi między zadaniami do wykonania a uzyskiwanymi korzyściami. Ustalony podział obowiązków nie wynikałby jednak z przyjęcia kulturowo ustanowionych kryteriów ani z przeszczepionych na grunt relacji nierówności ekonomicznych".

Konsensus miałby zastąpić groźby i szykany.

Opis ten kładzie nacisk na pełną refleksyjność aktorów oraz celowo-racjonalny charakter działań, a także przyjmuje wizję kultury jako kagańca, nakładanego wtórnie na aktora społecznego, który może się go po prostu pozbyć. Takie założenia $\mathrm{w}$ kontekście wszystkich przytoczonych dotychczas spostrzeżeń są bardzo ryzykowne w stosunku do jakiegokolwiek typu związku.

\section{WIELOPOZIOMOWOŚĆ I DYNAMIKA INTYMNOŚCI PRZEMIANY INTYMNOŚCI JAKO PRZEMIANY WIĘZI}

Podsumujmy dotychczasowe rozważania. Po pierwsze, można się zastanawiać, czy koncepcja Giddensa nie wyprzedza zbytnio swoich czasów - wówczas zarzucimy Giddensowi, że wyciągając wnioski pomija to, co kłóci się z tezą o rosnącym znaczeniu czystych relacji albo też że zbyt mało uwagi poświęca empirycznym świadectwom tego, jak wolno, wybiórczo, nie powszechnie i nie liniowo, lecz raczej w procesie walki sprzecznych sił i wyobrażeń przebiegają zmiany związków intymnych. Mówiąc krótko: relacje nie są tak „czyste”, jak wynikałoby to $z$ dyskursu terapeutycznego lub niektórych fragmentów książki Giddensa. Giddens w „pełnym otwarciu się na drugą osobę” i „zobaczeniu innych takimi, jakimi naprawdę są" widzi model związku, który tworzącym go partnerom ma przynieść uwolnienie od wcześniej gnębiących ich trosk i prawdziwą realizację idei intymności.

Dużo ważniejsza, bo czyni powyższą dyskusję bezprzedmiotową lub przynajmniej drugoplanową, jest druga grupa zastrzeżeń, dotyczących samej konceptualizacji przemian intymności oraz wiedzy ludzkiej i codziennego działania. Po pierwsze, należy odróżnić odrębne rodzaje i fragmenty wiedzy. Człowiek pragnie zwykle zaprezentować się jako osoba spójna i koherentna oraz redukować dostrzegane przez siebie lub wytykane przez innych dysonanse. Ponieważ jednak funkcjonuje $\mathrm{w}$ wielu różnych sieciach interakcyjnych, różnych wspólnotach, których wiedza nie jest koherentna, nabywa niekompatybilne fragmenty systemów wiedzy i musi wykonywać niemały wysiłek w celu ich integracji tym większy, im większe zmiany społeczne zaszły w określonym obszarze życia w ostatnich dziesięcioleciach. Związki intymne są takim obszarem, w którym zmiany bez wątpienia postępuja, dlatego tego rodzaju niespójności są nieuniknione i bardzo interesujące.

Po drugie, warto zwrócić uwagę na to, że ewentualne zmniejszenie się nierówności $\mathrm{w}$ związkach i wykształcanie się nowych ich modeli przebiega $\mathrm{w}$ toku tysięcy interakcji, wzajemnego układania się zarówno z samym sobą, 
jak i z partnerem. Sytuacja, w której dwie niosące w sobie rozmaite pęknięcia osoby podejmują wysiłek stworzenia intymnej relacji, obejmującej uwspólnienie wizji wielu codziennych praktyk, jest niezwykle ciekawa, początkowo często dynamiczna i otwarta. Osoby w parze wzajemnie się warunkują i modyfikują swoje oczekiwania. Częściej to kobiety, w wypadku których paleta potencjalnych modeli biografii uległa szczególnemu poszerzeniu, nieraz noszą dziś w sobie kilka odmiennych potencjalnych scenariuszy organizacji domowej codzienności. Ważne jest przy tym to, jakie scenariusze będzie gotowy realizować partner. Wiele kobiet musi też rozstrzygać jednocześnie własne dylematy dotyczące ról i biografii, ku którym pragną zmierzać, muszą radzić sobie ze swoimi dysonansami.

Wynik wielu mikrostarć, w których uciera się porządek domowy, jest jednak zmienny w czasie, dlatego - po trzecie - koniecznie trzeba zwrócić uwagę, na jakim etapie związku znajduje się para i w jakim stopniu stabilny, a w jakim wciąż jeszcze plastyczny jest układ, jaki tworzy. Związek jest procesem, co więcej, nie zmierza on wcale do coraz to większej i większej refleksyjności, lecz - jak niemal wszystkie ludzkie aktywności - z czasem zastyga $\mathrm{w}$ pewnych przyzwyczajeniach i mniej lub bardziej milczących regułach gry. Choć istnieją związki, które przez długi czas utrzymują się na określonym poziomie zaangażowania, partnerzy bowiem dbają o to, by nie stworzyć zbyt wielu pretekstów do ustanowienia trwałego porządku codzienności (np. odwlekając decyzję o wspólnym zamieszkaniu lub z niego rezygnując, nie kupując pralki, lecz piorąc poza domem itd.), w większości przypadków proces „unawykowienia" relacji i ustalenia reguł gry szybko postępuje.

Być może dobrym sposobem na stworzenie adekwatnej ramy dla badań intymności uwzględniających powyższe zastrzeżenia byłoby inne zdefiniowanie pojęcia więzi społecznej oraz ulubionego terminu Giddensa, jakim jest refleksyjność, a także tego, jaką rolę odgrywa ona w łączącej ludzi więzi. Czyste relacje tym według Giddensa odróżniają się od małżeństwa opartego na miłości romantycznej, że zawiązują się i trwają na bazie korzyści, jakie pragną czerpać ze związku oboje partnerzy, wybierający spośród konkurencyjnych ofert stwarzanych przez abstrakcyjne systemy późnej nowoczesności, a następnie refleksyjnie uzgadniający swoje projekty życiowe, tak by zgrać je ze sobą w ramach pewnego rodzaju „stowarzyszenia”.

Przyjęcie takich założeń prowadzi nas ku wizji człowieka od urodzenia obdarzonego zdolnością do refleksji, odwrotnie proporcjonalną do liczby instytucjonalnych ograniczeń, którym podlega i które ewentualnie częściowo zinternalizował (np. reguły wchodzenia w związki, represyjna moralność seksualna itd.). Kluczowa dla socjologii więź społeczna jest zaś wyłącznie „smyczą”, zmuszającą człowieka do określonych działań, albo też „pępowiną” - świadomą identyfikacją z określoną grupą i jej konformizmami lub interesami. Jak trafnie zauważają Mirosława Marody i Anna Giza-Poleszczuk, w takim wypadku zwierciadlanym odbiciem pojęcia więzi jest zbanalizowane pojęcie indywidualizacji, 
rozumianej wówczas po prostu ,jako proces psychologiczny stanowiący wyraz dojrzewania jednostki i jej uwalniania się z «opiekuńczych» więzów wspólnoty" (Marody, Giza-Poleszczuk 2006, s. 23). Łatwo wówczas określić współczesność — jak też czyni to wielu autorów (zob. Marody, Giza-Poleszczuk 2004, rozdz. 1) - jako „rozpad więzi”, kryzys dotychczasowych form życia społecznego lub triumf czystych relacji. Socjologia ma jednak wtedy do zaoferowania niewiele ciekawych analiz wykraczających poza eseistyczne ekstrapolacje trendów lub sumowanie sondażowych deklaracji oraz przyjmowanie na wiarę dominującej dziś wizji siebie jako autonomicznego, suwerennego, często czysto racjonalnego podmiotu (por. Kaufmann 2004).

Zupełnie inaczej dzieje się wówczas, gdy przyjmiemy pierwotność procesu uspołeczniania, bez którego żaden człowiek nie ma szans stać się podmiotem ludzkim, a więź zdefiniujemy jako „szansę odtworzenia pewnego układu społecznego, poprzez zrealizowanie się (powtórzenie) specyficznie zorientowanych interakcji na poziomie jednostkowym" (Marody, Giza-Poleszczuk 2006, s. 24). Więź to wówczas pewna trwała tendencja do wielokrotnego wchodzenia ludzi w zorganizowane układy działania. Jest ona „dynamicznym mechanizmem "grupowania» wciąż na nowo ludzi i przedmiotów w wiązkach skoordynowanego działania" (Marody, Giza-Poleszczuk 2006, s. 24). Jest zatem zarówno własnością układu, jak i własnością poszczególnych aktorów społecznych, którzy się na układ składają, dlatego ma charakter relacyjny: jest (a) relacją między aktorami, zachodzącą w odniesieniu do (b) konkretnego kontekstu sytuacyjnego. Marody i Giza-Poleszczuk proponują spojrzenie na więź społeczną jako logicznie (nie ontologicznie) pierwotną i wobec układu (całości społecznej), i wobec ludzi. To więzi, „ustawiając” względem siebie ludzi, składających się na przykład na rodzinę jako matki, ojcowie, dzieci itd., stwarzają zarówno jednostkę, jak i układ — jak pokazują także na przykład systemowe ujęcia w badaniach nad rodziną. Taka koncepcja więzi jest mniej intuicyjna, wymaga bowiem zastąpienia świata ujmowanego przedmiotowo światem ujmowanym jako zestaw procesualnych relacji (por. Elias 2008).

Jeśli zauważymy teraz, że człowiek należy współcześnie do różnych układów społecznych i różnych grup oraz przyswaja sobie różne i zmienne rodzaje wiedzy (wartości, filtrów poznawczych, ról), to refleksyjność możemy zdefiniować jako możliwość uzyskania dystansu wobec jednego układu/grupy z perspektywy innego układu/grupy (Giza-Poleszczuk 2005, s. 79), a na poziomie człowieka jako systemu postrzegającego swoje otoczenie — jako produkt konfliktu między przyzwyczajeniami lub alternatywnymi schematami działania (Kaufmann 2004, s. 154-155). Gdy taki schemat wchodzi w kolizję z innym, wówczas zmusza to do namysłu i wyboru, kolizje te są natomiast tym bardziej prawdopodobne, im większa jest szansa uzyskania przez aktora wspomnianego dystansu wobec układu interakcyjnego, który właśnie rozważa (por. Schmidt F. 2010).

Wzrastająca refleksyjność jest w związku z tym efektem nie tyle, albo przynajmniej nie tylko, „wyzwolenia” człowieka z zewnętrznych ograniczeń, ile 
rozziewu między jednym a drugim dyskursem, między odmiennymi wizjami związków, między powierzchownie przyswojonymi ideałami a głęboko zinternalizowanymi, sprzecznymi z nimi oczekiwaniami lub przyzwyczajeniami, a także między swoimi a jej/jego doświadczeniami w tych wszystkich zakresach. Prowadzi to do konieczności skupienia się właśnie na wynikających z tych różnic dysonansach i konfliktach.

Pojęcie refleksyjności opisuje zatem możliwość podania w wątpliwość starego porządku płci przez coraz intensywniejsze zastanawianie się nad działaniami alternatywnymi dla dotychczas oczywistego - na przykład nad naznaczonym wyraźnymi nierównościami małżeństwem rodziców z punktu widzenia dyskursu terapeutycznego poradników czy nad tym, jak zorganizować wesele tak, by wyjść na osobę nowoczesną, a jednocześnie spełnić swoje odwieczne marzenie o białej sukience $z$ długim welonem i bryczce.

Co wreszcie szczególnie istotne, generalnym dążeniem większości ludzi nie jest wspieranie procesu „urefleksyjniania” każdej dziedziny swojego życia, lecz przeciwnie - ciągłe dążenie do redukowania wszelkiego rodzaju poznawczych dysonansów, odciążanie umysłu i próba rozwiązywania różnych praktycznych dylematów (Festinger 2007; Kaufmann 2004; por. Schmidt F. 2010). Nadmierna refleksyjność skutkuje chroniczną niezdolnością do podjęcia decyzji. W sferze relacji międzypłciowych świetnym przykładem jest opisywane przez Michaela Meusera (1998a) fiasko wielu grup terapeutycznych przeznaczonych dla mężczyzn mających problemy ze swoją męskością i seksualnością, które oparte były na grupowej refleksji nad statusem męskości i ciągłym przepracowywaniu tworzących ją elementów. Efekt ich działania był często odwrotny do zamierzonego - ich założenia, bliskie tym przyjmowanym także przez Giddensa („w nowoczesnym życiu społecznym tożsamość, w tym tożsamość seksualna, jest osiągnięciem refleksyjnym”, s. 176), rodziły jeszcze większe problemy i były nie do zrealizowania. W rezultacie szybko wzrosła liczba grup terapeutycznych i samopomocowych opartych na założeniu całkowicie przeciwnym: dążących do umacniania wzruszonych przez refleksję podstaw tradycyjnych męskich ról społecznych, płciowych i seksualnych przez rozmaite formy aktywności sportowej, wspólne walki i inne zajęcia podejmowane w czysto męskiej grupie, podobnie jak dzieje się w filmie Fight Club Davida Finchera. Jeśli w ogóle przyjąć, że rolą socjologa jest wypowiadanie się na ten temat, to terapeutyczny nakaz „Porozmawiajmy o tym!” nie wydaje się uniwersalnym środkiem radzenia sobie $z$ codziennością. Nie koresponduje też $z$ tendencją ludzkiego systemu poznawczego do ciągłego redukowania złożoności świata i jego porządkowania.

Jeśli zgodzimy się na takie zdefiniowanie refleksyjności, to obecnie dokonujące się przemiany intymności w najogólniejszym zarysie moglibyśmy określić jako tendencję do „schładzania” związków, polegającą na zmniejszaniu się wagi Tönniesowskiej woli naturalnej kosztem woli arbitralnej (por. Marody, Giza-Poleszczuk 2006, s. 32-35) — zmniejszaniu się w pewnych obszarach „wspól- 
notowego" ich charakteru kosztem charakteru „stowarzyszeniowego”. Jest to oczywiście zmiana stopniowa, relatywna i nie mogąca przekroczyć pewnego progu. Niemal każdy bowiem związek intymny nabiera z czasem rysów wspólnotowych, a więc (a) dąży, przynajmniej w pewnym zakresie, do wytworzenia typowych dla wspólnoty stosunków opartych na współdziałaniu w ramach podzielanych upodobań, przyzwyczajeń i pamięci; (b) ustanawia specyficzną więź moralną między członkami, nakazującą partnerom przyjmowanie w każdej sytuacji punktu widzenia pary albo przynajmniej stałe współuwzględnianie partnera w każdej ważniejszej sferze życia (por. Luhmann 2003, s. 23); (c) działa za pośrednictwem silnego komponentu emocjonalnego, co sprawia, że ,jednostka czuje się nie tylko związana z grupą [związkiem - przyp. F.S.], jest również do niej przywiązana uczuciami miłości, wdzięczności, lojalności" (Marody, Giza-Poleszczuk 2006, s. 33) i dlatego łatwiej przyswaja punkt widzenia grupy oraz reguły działania jako swoje; (d) sprawia, że każdy z partnerów przynajmniej częściowo zawiera w sobie drugiego, tak że zagrożenie dla My staje się przynajmniej w pewnych kontekstach zagrożeniem dla Ja.

Można natomiast założyć, że w miarę jak podmioty wchodzące w związki w coraz większym stopniu są zdolne do dystansu względem swojej wiedzy, zyskują doświadczenia bycia $\mathrm{w}$ wielu związkach i są w stanie uczynić obiektem refleksji to, co dotychczas oczywiste, albo muszą zająć stanowisko wobec statusu swojej intymnej relacji w bardzo różnych kontekstach - w coraz większym stopniu są też $\mathrm{w}$ stanie przełamywać zastane, zakorzenione reguły zachowań i powiązane $z$ nimi uczucia i emocje. Te reguły i uczucia bronią się, ale wola arbitralna - coraz częściej pojawiająca się w nowych typach związków - stara się od nich uwolnić, a następnie rozbić je lub opanować. To, co na poziomie społecznym skutkuje „modernizacją” związków i przemianą charakteru ich więzi, na poziomie jednostkowym „ma jednak skutek w postaci nieciągłości między głęboko wcielonymi strukturami motywacyjnymi a świadomie podejmowanymi działaniami”. I w rezultacie — „W nastawieniu refleksyjnym jednostka może postanowić pragnąć czegoś, czego wartości nie czuje, robić rzeczy, których nie potrafi, oraz działać w sferze, której nie kontroluje" (Marody, Giza-Poleszczuk 2006, s. 35), a więc refleksyjność może narzucać aktorowi społecznemu cele niezgodne z preferencjami i umiejętnościami jego działania.

Zgodnie $z$ taką perspektywą patrzenia na związki intymne warto podczas analizy ich przemian szukać przede wszystkim tego, co w nich szczególnie konfliktowe, ambiwalentne i sprzeczne, a następnie zastanawiać się, w jakim stopniu tego rodzaju napięcia i pęknięcia są rozpowszechnione - jak w tym zakresie różne środowiskowe czy klasowe modele związków różnią się od siebie. Spróbuję wymienić kilka przykładów takich napięć i pęknięć dostrzegalnych $w$ badaniach empirycznych. Pierwszy z nich to omówiona wcześniej różnica między obowiązującym ideałem emancypacyjnym a faktycznymi zachowaniami. 90\% Polaków uważa, że mężczyźni powinni brać większy udział w pracach domowych, ale tylko $25 \%$ twierdzi, że faktycznie realizuje ideę domowego 
równouprawnienia, a tylko kilka procent zbliża się do niej w codziennych praktykach. Te rozbieżności blisko związane są z drugim rodzajem pęknięć, czyli częstym współwystępowaniem dwóch różnych logik myślenia i działania naraz. U kobiet jest to szczególnie często konflikt schematów związanych z samodzielnością, samorealizacją i równouprawnieniem oraz tych nakazujących za wszelką cenę znaleźć partnera i męża, tych odstręczających od roli gospodyni domowej i tych podsuwających pragnienie i gotowe umiejętności doskonałego organizowania i porządkowania swojego gospodarstwa domowego. Trzeci interesujący rodzaj sprzeczności to związane z Giddensowskim uplastycznieniem seksualności i zróżnicowaniem biografii związku rozmijanie się, w przypadku niektórych środowisk, obrazu idealnego męża z obrazem pociągającego mężczyzny, o czym jednozdaniowo wspomina także Giddens (s. 186-187). Czwarty konflikt to podwójne znaczenie posiadania partnera i/lub rodziny, co z jednej strony wiąże się z chęcią stworzenia wspólnego świata, $z$ drugiej zaś $-z$ akcesem do normalności i dorosłości, koniecznością biograficzną, dopuszczającą do świata „normalnych ludzi”. Z tego też powodu, jak pokazują niedawno przeprowadzone badania ludzi $\mathrm{w}$ średnim wieku $\mathrm{z}$ małych miast $\mathrm{w}$ Wielkopolsce (Drozdowski, Krajewski 2008), związek i rodzina jawią się z jednej strony jako absolutna oczywistość i życiowy cel numer jeden, z drugiej — jako podstawowy punkt zwrotny w życiu, ucinający niemal wszelkie indywidualne aspiracje i stanowiący podstawowe ograniczenie samorealizacji i wszelkich niestandardowych projektów życiowych.

Wreszcie piąta grupa konfliktów targających związkami to sprzeczności typowe dla modelu czystej relacji, które wymienia sam Giddens. Są to zwłaszcza: (a) konflikt między dążeniem do zaangażowania a założeniem o odwoływalności związku (daj z siebie wszystko, ale pamiętaj, ze nasza relacja może się za jakiś czas skończyć); (b) konflikt między bliskością a autonomią (otwórz się na drugiego, rozmawiaj, twórz wspólny świat, ale wyznacz wyraźne granice prywatnych światów obu partnerów); (c) konflikt między zaufaniem wobec partnera a zaufaniem wobec przyjaciela/przyjaciółki (komu mogę się zwierzać, wobec kogo być bardziej lojalnym, czy partnerowi należy mówić wszystko?). Myślę, że można zaryzykować tezę, że wszystkie te konflikty stanowią po części wynik przemieszania się sposobów regulacji działań typowych dla dwóch różnych rodzajów więzi i dla różnych modelów związku intymnego.

Powyższe rozważania nie miały prowadzić do całkowitego zaprzeczenia koncepcji stworzonej przez autora Przemian intymności. Z trzech powodów uważam jednak, że zaproponowany sposób analizy przemian w zakresie związków intymnych jest przydatny. Po pierwsze, pozwala w mniejszym stopniu opierać się na ogólnych tendencjach przemian kulturowych, a w większym na wielotorowej analizie sposobów radzenia sobie z pewnymi uniwersalnymi pytaniami 
i dylematami, które stoją przed osobami tworzącymi związek intymny. Po drugie, służy koncentracji na dynamice płynącej z tych dylematów, a nie po prostu na relacji między dawniej a dziś i stopniu przejścia od „tradycyjnego” do „ponowoczesnego" modelu związku i klasyfikowaniu par do którejś z tych grup. Po trzecie, pozwala uniknąć zagrażających koncepcji Giddensa uproszczeń, które mogą poprowadzić w ślepą uliczkę. Przykładem niech będzie fragment tekstu Bernadette Bawin-Legros (2004, s. 241-242):

„Jak pisze Anthony Giddens [w Przemianach intymności], wpływy tradycyjnych źródeł władzy i więzi społecznych radykalnie osłabły na korzyść niekończącego się i obsesyjnego zaabsorbowania osobistą tożsamością. [...] Zamiast stopniowego i powolnego konstruowania własnej tożsamości, na wzór, powiedzmy, budowania domu, $\mathrm{w}$ coraz większym stopniu pociągają nas dziś nowe początki i spontaniczne więzi. Skutkiem jest tożsamość, która przyjmuje formę palimpsestu, dla której zapominanie jest ważniejsze niż pamiętanie. [...] Jesteśmy turystami naszej prywatnej krainy i wkroczyliśmy w świat czystego indywidualizmu".

Taka interpretacja Giddensa zmusza nas do przyjęcia jednowymiarowej osi analizy, na której końcach mamy z jednej strony „więź społeczną”, a z drugiej „osobistą tożsamość", przemiany związków intymnych zaś każe opisać jako podróż między krańcami takiego kontinuum. Niewiele dowiadujemy się też przy takim ujęciu tematu o faktycznej codzienności współczesnych par, z których większość nie bardzo daje się wpasować w model "czystego indywidualizmu” i rolę „turystów swojej prywatnej krainy”. Taka interpretacja pociąga za sobą także ryzyko idyllicznego i skrzywionego spojrzenia na związki w przeszłych pokoleniach oraz sądów moralizujących. Można na przykład stwierdzić, że:

„W poprzednich pokoleniach [...] podstawowymi czynnikami scalającymi związki małżeńskie były przede wszystkim wspólne projekty, wspólne zainteresowania, posiadane dzieci, wzajemna przyjaźń, szacunek, zaufanie, a na dalszym etapie przywiązanie. [...]

Dzisiejszy «czysty związek» [...] jest inwestycją, bilateralna umową, związaną $z$ nieodłącznym rachunkiem zysków i strat. Odejście $z$ tak pojmowanego związku pociągałoby za sobą konieczność utraty istotnych inwestycji, jakie poczynili partnerzy [...]. Jest to swego rodzaju koalicja oparta na «wspólnocie interesów». [...] Utrzymuje się, dopóki partnerzy dostarczają sobie dość zadowolenia. Coraz częściej bowiem ludzie dziś bawią się, grają w związek, konsumują go jak atrakcyjny towar" (Bieńko 2006, s. 112-113).

Refleksyjność łatwo staje się frazesem; czysta relacja może zostać bez trudu określona jako czyste stowarzyszenie, pozbawione wspólnotowego nakładania się światów, nie bardzo zresztą wiadomo, na czym się w ogóle opierające, a przyjęcie za dobrą monetę punktu widzenia suwerennej jednostki nie tylko sprawia, że znów poruszamy się po tej samej, jednowymiarowej, fałszywej osi, jeszcze głębiej wkraczając w jałowy dyskurs moralizujący. Na tej samej zasadzie 
można na przykład zastanawiać się, czy bycie singlem to „indywidualizm czy legitymizowany egoizm" (Bieńko 2006, s. 108-110).

Ostrożna analiza związku jako dynamicznego procesu i sieci relacji, a także potraktowanie różnych skomplikowanych i konfliktogennych historii zawiązywania współczesnych relacji intymnych jako odzwierciedlenia rozmaitych strukturalnych niedopasowań oraz odpowiadających im jednostkowych dylematów pozwala rozszerzyć analizę Giddensa, a już na pewno wydaje się perspektywą dużo płodniejszą dla socjologii życia intymnego niż jednowymiarowe rozważania nad „czystą indywidualizacją”, „kryzysem więzi” albo „zmierzchem małżeństwa”. Tym bardziej że bez wątpienia Giddens ma rację pisząc, iż głębsze przemiany $\mathrm{w}$ tej dziedzinie muszą być skorelowane $\mathrm{z}$ głębszymi przemianami $\mathrm{w}$ innych sferach życia codziennego. A modele przemian intymności, można by dodać, muszą zakładać jakiś model przemian więzi społecznej oraz w satysfakcjonujący sposób korespondować z pewnymi ogólnymi założeniami dotyczącymi wiedzy ludzkiej i jej stosowania w działaniu.

\section{BIBLIOGRAFIA}

Bauman Zygmunt, 1998, Über den postmodernen Gebrauch der Sexualität, „Zeitschrift für Sexualforschung", t. 11, s. 1-16.

Bawin-Legros Bernadette, 2004, Intimacy and the New Sentimental Order, „Current Sociology", t. 52, nr 2, s. 241-250.

Baxter Janeen, 2000, The Joys and Justice of Housework, „Sociology”, t. 35, s. 609-631.

Beck Ulrich, Beck-Gernsheim Elisabeth, 2005, Das ganz normale Chaos der Liebe, Suhrkamp, Frankfurt am Main.

Bieńko Mariola, 2006, Nieznośna lekkość więzi $w$ sferze bliskich kontaktów międzyludzkich, „Societas/Communitas”, nr 1, s. 105-126.

Bock Gisela, Duden Barbara, 2000, Geschichte der Hausarbeit, w: Arbeit, Sozialisation, Sexualität: zentrale Felder der Frauen- und Geschlechterforschung, Andrea Buehrmann, Angelika Diezinger, Sigrid Metz-Goeckel (red.), Leske+Budrich, Opladen.

Budrowska Bogusława, 2005, Nieodptatna praca kobiet i próby jej wyceny, http://www. ekologiasztuka.pl/pdf/fe007budrowska.pdf [28.01.2009].

Burkart Günter, Koppetsch Cornelia, 1999, Die Illusion der Emanzipation. Zur Wirksamkeit latenter Geschlechtsnormen in Milieuvergleich, UVK, Konstanz.

Doucet Andrea, 2001, „You See the Need Perhaps More Clearly Than I Have”: Exploring Gendered Processes of Domestic Responsibility, „Journal of Family Issues”, t. 22, s. 328-357 .

Drozdowski Rafał, Krajewski Marek (red.), 2008, Wyobraźnia społeczna. Horyzonty źródta - dynamika, Wydawnictwo Naukowe UAM, Poznań.

Duch-Krzystoszek Danuta, 2007, Kto rzadzi w rodzinie, Socjologiczna analiza relacji w matżeństwie, IFiS PAN, Warszawa.

Duerr Hans Peter, 1988, Nacktheit und Scham (Der Mythos vom Zivilisationsprozeß, t. 1), Suhrkamp, Frankfurt am Main.

Duerr Hans-Peter, 1997, Der Erotische Leib (Der Mythos vom Zivilisationsprozeß, t. 4), Suhrkamp, Frankfurt am Main. 
Elias Norbert, 2008, Społeczeństwo jednostek, tłum. Janusz Stawiński, Wydawnictwo Naukowe PWN, Warszawa.

Festinger Leon, 2007, Teoria dysonansu poznawczego, Wydawnictwo Naukowe PWN, Warszawa.

Giddens Anthony, 2001, Nowoczesność $i$ tożsamość. „Ja” $i$ społeczeństwo $w$ epoce późnej nowoczesności, tłum. Alina Szulżycka, Wydawnictwo Naukowe PWN, Warszawa.

Giddens Anthony, 2003, Stanowienie społeczeństwa. Zarys teorii strukturacji, tłum. Stefan Amsterdamski, Zysk i S-ka, Poznań.

Giddens Anthony, 2006 [1992], Przemiany intymności. Seksualność, mitość i erotyzm we wspótczesnych społeczeństwach, tłum. Alina Szulżycka, Wydawnictwo Naukowe PWN, Warszawa.

Giza-Poleszczuk Anna, 2005, Rodzina a system społeczny. Reprodukcja i kooperacja w perspektywie interdyscyplinarnej, Wydawnictwa Uniwersytetu Warszawskiego, Warszawa.

Gdula Maciej, 2009, Trzy dyskursy miłosne, Oficyna Naukowa, Warszawa.

Hinz Michael, 2002, Der Zivilisationsprozess: Mythos oder Realität? Wissenschaftliche Untersuchungen zur Elias-Duerr-Kontroverse, Leske+Budrich, Opladen.

Holmes Mary, 2004, The Precariousness of Choice in the New Sentimental Order: A Response to Bawin-Legros, „Current Sociology”, t. 52, s. 251-257.

Jamieson Lynn, 1999, Intimacy Transformed? A Critical Look at the "Pure Relationship", „Sociology”, t. 33, s. 477-494.

Jewdokimow Marcin, Garncarek Magdalena, 2008, W pót kroku. Single o sobie samych, „Societas/Communitas”, nr 4-5.

Kaufmann Jean-Claude, 1994, Schmutzige Wäsche. Zur ehelichen Konstruktion von Alltag, UVK, Konstanz.

Kaufmann Jean-Claude, 1999, Mit Leib und Seele. Theorie der Haushaltstätigkeit, UVK, Konstanz.

Kaufmann Jean-Claude, 2002, Singlefrau und Märchenprinz: Warum viele Frauen lieber allein leben, UVK, Konstanz.

Kaufmann Jean-Claude, 2004, Ego. Socjologia jednostki, tłum. Krzysztof Wakar, Oficyna Naukowa, Warszawa.

Kaufmann Jean-Claude, 2005, Der morgen danach. Wie eine Liebesgeschichte entsteht, Goldmann, München.

Künzler Jan, 1994, Familiale Arbeitsteilung. Die Beteiligung von Männern an der Hausarbeit, Kleine Verlag, Bielefeld.

Lew-Starowicz Zbigniew, 2007, Intymność i refleksyjność (recenzja książki Przemiany intymności A. Giddensa), „Nowe Książki”, nr 3.

Luhmann Niklas, 2003, Semantyka miłości. O kodowaniu intymności, tłum. Jerzy Łoziński, Scholar, Warszawa.

Marody Mirosława, 1996, Pojęcie wartości w wyjaśnianiu zachowań społecznych, w: Mirosława Marody, Ewa Gucwa-Leśny (red.), Podstawy życia społecznego w Polsce, Instytut Studiów Społecznych, Warszawa.

Marody Mirosława, Giza-Poleszczuk Anna, 2004, Przemiany więzi społecznych, Scholar, Warszawa.

Marody Mirosława, Giza-Poleszczuk Anna, 2006, W uwięzi więzi (społecznych), „Societas/Communitas", nr 1.

Meuser Michael, 1998a, Geschlecht und Männlichkeit: soziologische Theorie und kulturelle Deutungsmuster, Opladen. 
Meuser Michael, 1998b, Vergesellschaftete Intimität. Geschlechterpolitik und Liebe, w: Kornelia Hahn, Günter Burkart (red), Liebe am Ende des 20. Jahrhunderts. Studien zur Soziologie intimer Beziehungen, Leske+Budrich, Opladen.

Przybył Iwona, Żurek Aldona, 2007, Tożsamość socjologii rodziny - utrata czy tworzenie nowych podstaw badawczych. Kondycja polskiej socjologii rodziny w ostatnim piętnastoleciu, w: Końce i początki. Socjologiczne podsumowania, socjologiczne zapowiedzi, Wydawnictwo Naukowe UAM, Poznań.

Ronek Grzegorz, 2008, Koncepcja demokratycznej rodziny Anthony'ego Giddensa, w: Wojciech Muszyński, Ewa Sikora (red.), Miłość, wierność $i$ uczciwość na rozstajach wspótczesności. Kształty rodziny wspótczesnej, Wydawnictwo Adam Marszałek, Toruń.

Sanchez Laura, 1994, Material Resources, Family Structure Resources, and Husbands', Housework Participation: A Cross-National Comparison, „Journal of Family Issues”, t. 15, s. $379-402$.

Schmidt Filip, 2010, Teorie kuchenne. Dialektyka przyzwyczajeń $i$ refleksyjności $w$ koncepcji Jeana-Claude’a Kaufmanna, „Kultura i Społeczeństwo”, nr 1.

Schmidt Günter, 2004, Das neue Der Die Das. Über die Moderniesierung des Sexuellen, Psychosozial Verlag, Gießen.

Schmidt Günter i in., 2006, Beziehungsformen und Beziehungsverläufe im sozialen Wandel. Eine empirische Studie an drei Generationen, „Zeitschrift für Sexualforschung” nr 16, s. $1-38$.

Schröter Michael, 1997, Erfahrungen mit Norbert Elias. Gesammelte Aufsätze, Suhrkamp, Frankfurt.

Sekuła Elżbieta Anna, 2006, Giddens o miłości i nie tylko [recenzja książki Przemiany intymności A. Giddensa], „Kultura Popularna”, nr 4.

Starke Kurt, 2005, Nichts als die reine Liebe. Beziehungsbiographien und Sexualität im sozialen und psychologischen Wandel, Pabst, Lengerich.

Szczepańska Joanna, 2006, Kobiety i mężczyźni o podziale obowiązków domowych, raport CBOS, lipiec 2006, http://www.cbos.pl/SPISKOM.POL/2006/K_183_06.PDF [10.01.2008].

Titkow Anna, 2006, Tożsamość polskich kobiet: ciagłość, zmiana, konteksty, IFiS PAN, Warszawa.

Titkow Anna, Duch-Krzystoszek Danuta, Budrowska Bogusława, 2004, Nieodpłatna praca kobiet: mity, realia, perspektywy, IFiS PAN, Warszawa

Wouters Cas, 1999, Informalisierung Norbert Elias' Zivilisationstheorie und Zivilisationsprozesse im 20. Jahrhundert, Westdeutscher Verlag, Opladen.

Wouters Cas, 2004, Sex and Manners: Female Emancipation in the West 1890-2000, Sage, London.

Żurek Aldona, 2008, Single: żyjąc w pojedynkę, Wydawnictwo Naukowe UAM, Poznań.

IMPURE RELATIONSHIPS, AMBIVALENCES AND TENSIONS

IN CONTEMPORARY INTIMATE RELATIONSHIPS:

A CRITICAL VIEW OF ANTHONY GIDDENS' THEORY

Summary

The article discusses contemporary changes in intimate relationships. A starting point for this discussion is Anthony Giddens's theory presented in his book The Trans- 
formation of Intimacy (1992), particularly the specificity of self-help literature as a source of information for sociological reasoning. On the example of housework, the nature of the tensions between the conflict expectations of partners is presented. Today, many people are torn between several different models of intimate relations and different needs. The thesis of the article is that the ambivalence observed in the process of relationship formation is neither marginal nor only psychological but it represents tensions between different types and dimensions of knowledge which are used in this process. This ambivalence is also a perfect indicator of the discourse struggle in the public sphere and an element of changes of social bonds; its study may help answer the question about transformation of intimacy and about the commonness of "pure relations" or other models of intimate relationships.

\section{Key words/słowa kluczowe}

Anthony Giddens; intimacy / intymność; everyday life / codzienność; reflexivity / refleksyjność; social change / zmiana społeczna; housework / prace domowe; sexual inequalities / nierówności płciowe 